\title{
Comprehensive analytical characteristics of $N$-(adamantan-1-yl)-1- (cyclohexylmethyl)-1H-indazole-3-carboxamide (ACHMINACA)
}

\author{
Michal P. Dybowski ${ }^{1}\left[\right.$ ? Piotr Holowinski ${ }^{1} \cdot$ Rafal Typek $^{1} \cdot$ Andrzej L. Dawidowicz $^{1}$
}

Received: 10 July 2020 / Accepted: 10 August 2020 / Published online: 28 August 2020

(c) The Author(s) 2020

\begin{abstract}
Purpose The aim of this study was to clarify the most essential analytical features of $N$-(adamantan-1-yl)1-(cyclohexylmethyl)- $1 H$-indazole-3-carboxamide (one of the newest cannabimimetics called ACHMINACA), to make them useful for analytical identification of this compound.

Methods The compound was analyzed by gas chromatography-mass spectrometry, high-resolution liquid chromatography-mass spectrometry, crystal X-ray diffraction and spectroscopic methods such as nuclear magnetic resonance, Raman, and infrared spectroscopies.

Results Detailed and comprehensive analytical data have been acquired for ACHMINACA.

Conclusions Although brief descriptions of the partial data of ACHMINACA have appeared recently, this article provides the most detailed and comprehensive analytical data of ACHMINACA to our knowledge. Our data will significantly broaden the knowledge about the compound structure extending the possibility of its orthogonal analysis. The gathered data are useful for forensic, toxicological, and clinical purposes.
\end{abstract}

Keywords ACHMINACA $\cdot$ Analytical characteristics $\cdot$ Mass spectrometry $\cdot$ X-ray crystallography $\cdot$ Infrared, Raman and UV-VIS spectroscopies · NMR spectroscopy

\section{Introduction}

A characteristic feature of the contemporary market of illegal substances is the huge supply of novel psychoactive compounds. Hundreds of them have been registered over the last 10 years by specialized European and United Nations offices, such as the European Monitoring Centre for Drugs and Drug Addiction and the United Nations Office on Drugs and Crime [1,2]. Among them, synthetic cannabinoids constitute one of the most numerous and widespread groups. Their structural evolvement started with the modification of compounds containing the cyclohexylphenol or arylindole ketone core [3,4]. Over the course of 10 years, many

Electronic supplementary material The online version of this article (https://doi.org/10.1007/s11419-020-00547-6) contains supplementary material, which is available to authorized users.

Michal P. Dybowski

m_dybowski@interia.pl

1 Department of Chromatography, Institute of Chemical Sciences, Faculty of Chemistry, Maria Curie Sklodowska University in Lublin, 20-031 Lublin, Poland derivatives of these compounds have appeared on the market, e.g., indole- and indazole carboesters, indole- and indazole carboxamides, indole-2,2,3,3-tetramethylcyclopropyl ketones, pyrazole carboxamides and other groups [5-9]. A multitude of substituents meeting the requirements for the cannabimimetic activity that can be attached to the enlisted core scaffolds and possible regioisomerism [4, 10-12] further expand the structural variety of synthetic cannabinoids. Until recent years, synthetic cannabinoids with adamantyl (tricyclo[3.3.1.13,7]dec-1-yl) moiety (e.g. AB-001, APICA, APINACA, APINAC, and AMPPPCA [8, 12-17]) have been more and more frequently available on the black market of illegal substances which has increased a need for new reliable methods of their detection.

This article presents comprehensive analytical characteristics of a novel synthetic cannabinoid seized by Polish law enforcement authorities-ACHMINACA, $N$-(adamantan1-yl)-1-(cyclohexylmethyl)-1 $H$-indazole-3-carboxamide (see Fig. 1). This analog of APINACA, with the cyclohexylmethyl group in place of the pentyl chain, was examined using the following methods: gas chromatography coupled with mass spectrometry (GC-MS); attenuated total reflection 


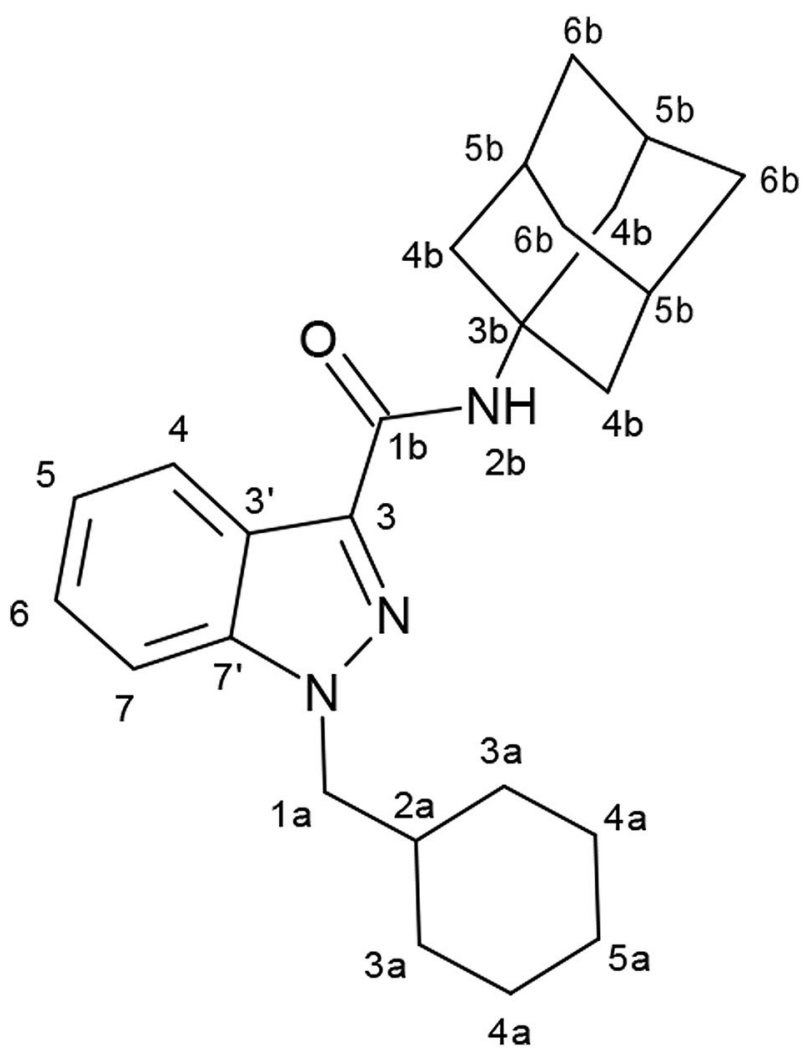

Fig. 1 Chemical structure of $N$-(adamantan-1-yl)1-(cyclohexylmethyl)- $1 H$-indazole-3-carboxamide (ACHMINACA)

(ATR) Fourier-transform infrared (FTIR) spectroscopy; nuclear magnetic resonance (NMR) spectroscopy; liquid chromatography with ultraviolet-visible (UV-VIS) photodiode array (PDA) and with mass spectrometry detection (LC-PDA-MS); and powder and single crystal X-ray diffraction. To the best of our knowledge, complete structural characterization of ACHMINACA has not been reported yet in scientific literature; only a few spectroscopic data are available from SWGDRUG and Slovenian Police reports [18, 19].

\section{Materials and methods}

\section{Materials}

Acetonitrile and methanol (all LC-MS grade) were purchased from the Polish Chemical Plant POCh (Gliwice, Poland); formic acid from Sigma-Aldrich (Seelze, Germany); deuterated chloroform from Armar AG (Döttingen, Switzerland); the Milli-Q system from Millipore (Millipore, Bedford, MA, USA) applied for water purification. ACHMINACA sample was donated by the forensic laboratory of the
Provincial Police Station in Lublin. Working solutions were stored under stable conditions at $-20{ }^{\circ} \mathrm{C}$.

\section{GC-MS analysis}

Qualification of the compound in the prepared sample was performed using GC/MS QP2010 (Shimadzu, Kyoto, Japan). A ZB5-MS fused-silica capillary column $(30 \mathrm{~m} \times 0.25 \mathrm{~mm}$ i.d., $0.25 \mu \mathrm{m}$ film thickness; Phenomenex, Torrance, CA, USA) was used. Helium (grade 5.0) was used as a carrier gas. One microliter of the sample was injected by an AOC20i type autosampler (Shimadzu). The injector's temperature was $310{ }^{\circ} \mathrm{C}$. The following temperature program was applied: start at $50{ }^{\circ} \mathrm{C}$, a linear temperature increase up to $315^{\circ} \mathrm{C}$ at the rate of $7{ }^{\circ} \mathrm{C} \times \mathrm{min}^{-1}$ and hold for $20 \mathrm{~min}$. The mass spectrometer was operated in electron ionization (EI) mode at $70 \mathrm{eV}$; the ion source temperature was $220^{\circ} \mathrm{C}$. The mass spectra were measured in the range 35-400 amu. Qualitative analysis was carried out comparing the retention indices and MS spectra for the obtained peaks with the analogous data from the NIST14 database. Additionally, the retention index of the component was calculated according to [20].

\section{LC-MS analysis}

The chromatographic measurements were performed on a high-resolution (HR) LC-MS system consisting of a ultrahigh-performance liquid chromatography (UHPLC) instrument (UltiMate 3000; Dionex, Sunnyvale, CA, USA), a linear trap quadrupole-Orbitrap mass spectrometer (LTQOrbitrap Velos from Thermo Fisher Scientific, San Jose, CA, USA) and an electrospray ionization (ESI) source. A Gemini C18 column $(100 \times 4.6 \mathrm{~mm}$ i.d., $3 \mu \mathrm{m}$ particle size; Phenomenex) was employed for chromatographic separation performed using isocratic elution (Phenomenex pre-column, $3 \times 4 \mathrm{~mm}$ i.d, $3 \mu \mathrm{m}$ particle size, was used for column protection). The mobile phase was acetonitrile/water $(75: 25, \mathrm{v} / \mathrm{v})$. The total run time was $45 \mathrm{~min}$ at the mobile phase flow rate of $0.5 \mathrm{~mL} / \mathrm{min}$. In the course of each run, PDA spectra in the range of 190-600 $\mathrm{nm}$ and MS spectra in the range of $\mathrm{m} / \mathrm{z}$ 100-1000 were collected continuously. The ESI source was operated in the positive mode under the following specific conditions: spray voltage, $3.5 \mathrm{kV}$; sheath gas, 40 arbitrary units; auxiliary gas, 10 arbitrary units; sweep gas, 10 arbitrary units; and capillary temperature, $320^{\circ} \mathrm{C}$. Nitrogen (99.98\%) was employed as the sheath, auxiliary and sweep gases. The scan cycle was used for a full-scan event at the resolution of 60,000 . 


\section{MS analysis with direct flow injection}

The solution of the examined compound in methanol $(0.1 \mathrm{mg} / \mathrm{mL})$ was directly introduced at the rate of $100 \mu \mathrm{L} /$ min to the ion source of the ion-trap mass spectrometric system (LCQ Advantage Max; Thermo Finnigan, San Jose, CA, USA). The ESI needle potential was $4.5 \mathrm{kV}$ in the positive ionization mode. The function of secondary ion fragmentation $\left(\mathrm{MS}^{2}\right)$ was applied for the value at $m / z$ 392. The collision energy was $25 \%$.

\section{ATR-FTIR}

The infrared spectrum of the examined compound was registered using a Nicolet ${ }^{\mathrm{TM}} \mathrm{iS} 50$ FTIR spectrometer (Thermo Fisher Scientific, San Jose, CA, USA) with ATR crystal, employing the spectral range from 4000 to $400 \mathrm{~cm}^{-1}$. The spectrum of the obtained solid sample was acquired without any sample pretreatment.

\section{Raman spectroscopy}

Acquisition of Raman spectrum for the ACHMINACA powder sample was performed using inVia Reflex Raman microscope (Renishaw, Wotton-Under-Edge, Gloucestershire, UK) equipped with a $785 \mathrm{~nm}$ semiconductor laser. The data were collected in the wavenumber range from 500 to $3500 \mathrm{~cm}^{-1}$.

\section{NMR spectroscopy}

For the NMR analysis, $10 \mathrm{mg}$ of the seized material was dissolved in $0.5 \mathrm{~mL}$ of $\mathrm{CDCl}_{3}$, centrifuged and transferred to a $5 \mathrm{~mm}$ NMR tube. The acquisition of NMR spectra was performed using an Ascend 600 spectrometer (Bruker, Bremen, Germany). The following NMR techniques were employed to elucidate the structure of the examined compound and to assign the NMR signals:

- 1D: ${ }^{1} \mathrm{H},{ }^{13} \mathrm{C}$, selective ${ }^{1} \mathrm{H}-{ }^{1} \mathrm{H}$ total correlated spectroscopy (s-TOCSY)

- 2D: ${ }^{1} \mathrm{H}-{ }^{1} \mathrm{H}$ correlation spectroscopy (COSY), ${ }^{1} \mathrm{H}-{ }^{1} \mathrm{H}$ nuclear Overhauser effect spectroscopy (NOESY), ${ }^{1} \mathrm{H}-$ ${ }^{13} \mathrm{C}$ multiplicity edited heteronuclear single quantum coherence (e-HSQC) spectroscopy, ${ }^{1} \mathrm{H}^{13} \mathrm{C}$ heteronuclear multiple bond correlation (HMBC) spectroscopy, and refocused 1,1 adequate sensitivity double quantum transfer experiment (1,1-ADEQUATE) spectroscopy.

The chemical shifts of ${ }^{1} \mathrm{H}$ and ${ }^{13} \mathrm{C}$ nuclei were calibrated using the internal reference signals (tetramethylsilane: TMS).

\section{Powder X-ray diffraction}

The powder diffraction measurements of the seized material were performed using an Empyrean diffractometer (PANalytical, Malvern, UK) employing $\mathrm{Cu}$ anode (voltage: $-40 \mathrm{kV}$; current: $25 \mathrm{~mA}$ ) and $2 \theta$ range from $4.96^{\circ}$ to $90.03^{\circ}$ with the step size of $0.026^{\circ}$.

\section{Single crystal diffraction}

The single-crystal data were collected at $20{ }^{\circ} \mathrm{C}$ using a Rigaku XtaLAB diffractometer with a MicroMax-007 HF rotated anode X-ray source and Pilatus $200 \mathrm{~K}$ surface detector (Rigaku Corporation, Tokyo, Japan). The CrysAlisPro software (Rigaku Corporation) was used for the collection, integration, and analysis of the obtained data. The crystal structure was solved by direct methods using the SHELXS-97 program and refined using the SHELXL-97 program [21].

\section{Results}

\section{GC-MS}

Figure 2 a shows the GC-MS chromatogram of methanolic solution of the examined compound, whereas its MS spectrum and possible structures of the most important fragment ions are presented in Fig. 3, showing that sized compound was almost pure. As results from Fig. 3a, EI-MS spectrum, contains, besides molecular ion at $\mathrm{m} / z$ 391 , several intense peaks of fragmentation products $(\mathrm{m} / \mathrm{z}$ 363, 294, 241, 150, 145 and 135). The corresponding possible structures of those ions are presented in Fig. 3b. The main ion at $\mathrm{m} / \mathrm{z}, 241$ corresponds to the acylium indazolealkyl ion. Its $m / z$, due to the presence of cyclohexylmethyl instead of the typically encountered alkyl chain $N$-indazole substituents, differs from $\mathrm{m} / \mathrm{z}$ for similar ions of other $\mathrm{N}$-adamantyl amide cannabinoids. Two ions, at $\mathrm{m} / \mathrm{z} 135$ and 150, deserve particular attention. They prove the presence of adamantyl moiety attached to amide nitrogen in the examined compound. The EI-MS spectrum presented in Fig. 3a was similar to that for ACHMINACA described in the SWGDRUD database [18]. The estimated retention index equaled 3081 .

\section{LC-MS and direct flow injection ESI-MS ${ }^{2}$}

The exemplary LC-MS chromatogram of ACHMINACA methanolic solution is shown in Fig. 2b, whereas HR-MS 

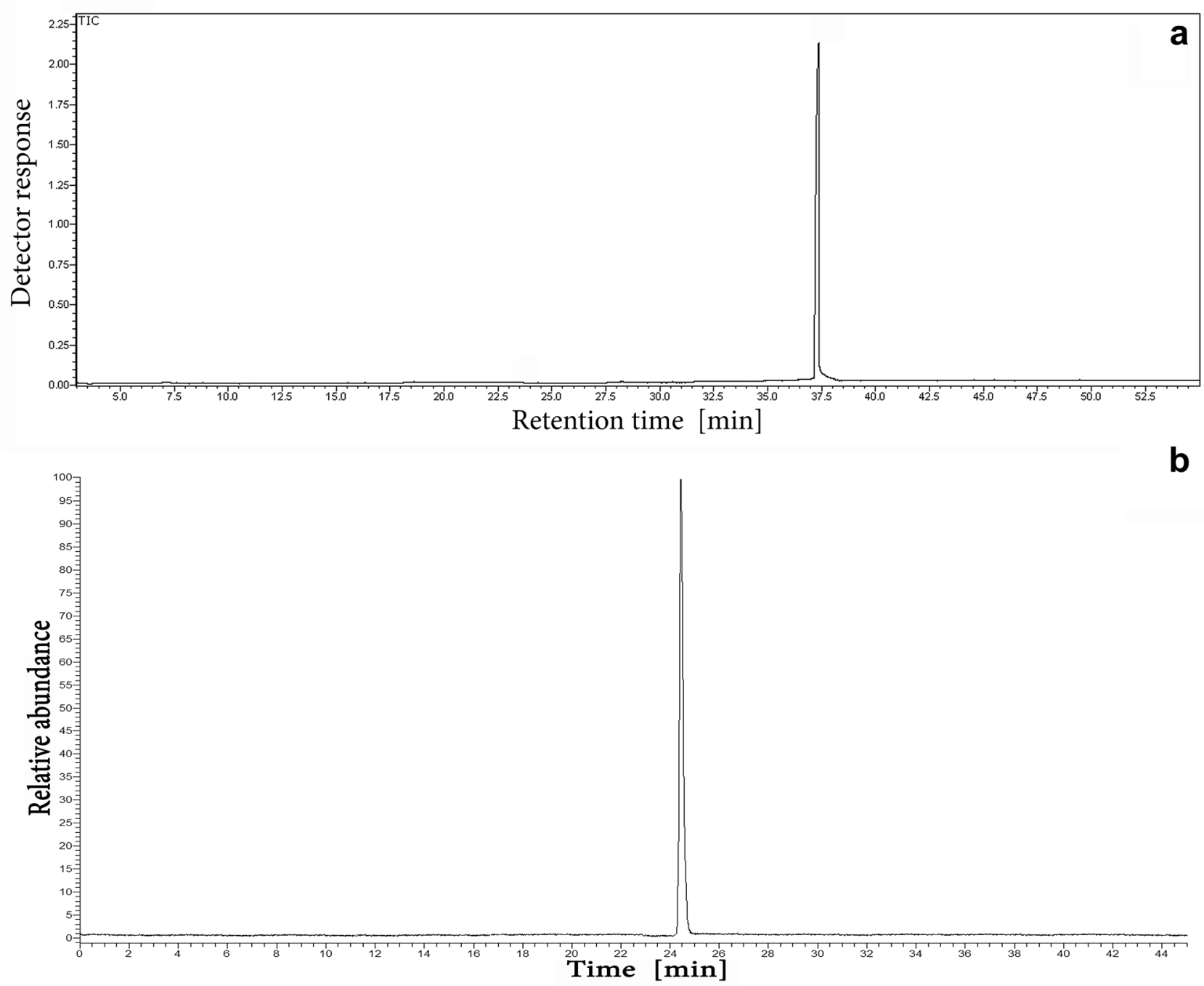

Fig. 2 a Gas chromatography-mass spectrometry (GC-MS) and b liquid chromatography-mass spectrometry (LC-MS) total ion chromatograms of ACHMINACA

data corresponding to this compound is gathered in Table 1 . The obtained data indicated the following molecular weight of ACHMINACA $[\mathrm{M}+\mathrm{H}]^{+}$ion and its elemental composition: 392.27011 Da and $\mathrm{C}_{25} \mathrm{H}_{33} \mathrm{~N}_{3} \mathrm{O}$, respectively. The very low difference between the theoretical and the experimental mass $(\Delta \mathrm{ppm})$ for ACHMINACA ions proved the correctness of the elemental analysis.

The $m / z$ values and intensities of individual product ions obtained by direct injection of ACHMINACA solution into the ion source of the ion-trap mass spectrometer are also collected in Table 1. The three most intensive fragment ions at $\mathrm{m} / \mathrm{z} 134.8,257.5$, and 258.7 , indicate the similarity between ESI and EI fragmentation patterns (see Fig. 4).

\section{IR, Raman, and UV-VIS spectroscopies}

The IR spectrum of the examined compound is shown in Fig. S1 (see Supplementary material). The following characteristic bands could be distinguished for ACHMINACA:

- two bands of secondary amide group representing carbonyl stretching and $\mathrm{N}-\mathrm{H}$ bending modes at $1655 \mathrm{~cm}^{-1}$ and $1524 \mathrm{~cm}^{-1}$, respectively;

- weak bands of $\mathrm{N}-\mathrm{H}$ stretching around $3400 \mathrm{~cm}^{-1}$;

- asymmetric aromatic ring stretching vibrations appearing at $1490 \mathrm{~cm}^{-1}$ along with out-of-plane bending of aromatic ring and $\mathrm{C}-\mathrm{H}$ bonds modes giving rise to the signals in the region of 800 to $700 \mathrm{~cm}^{-1}$. 


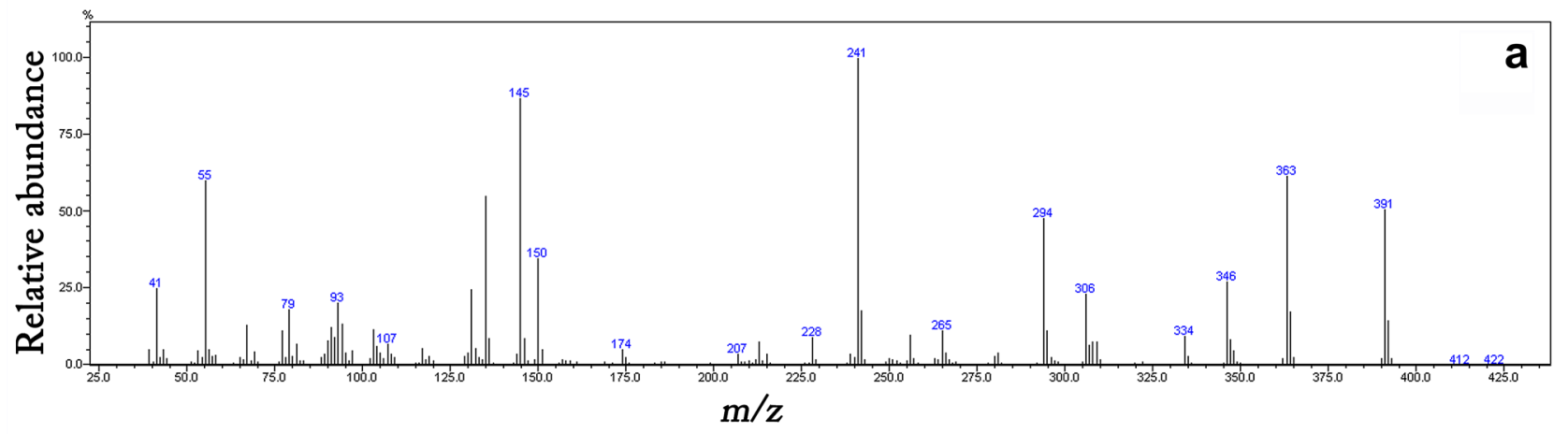

b

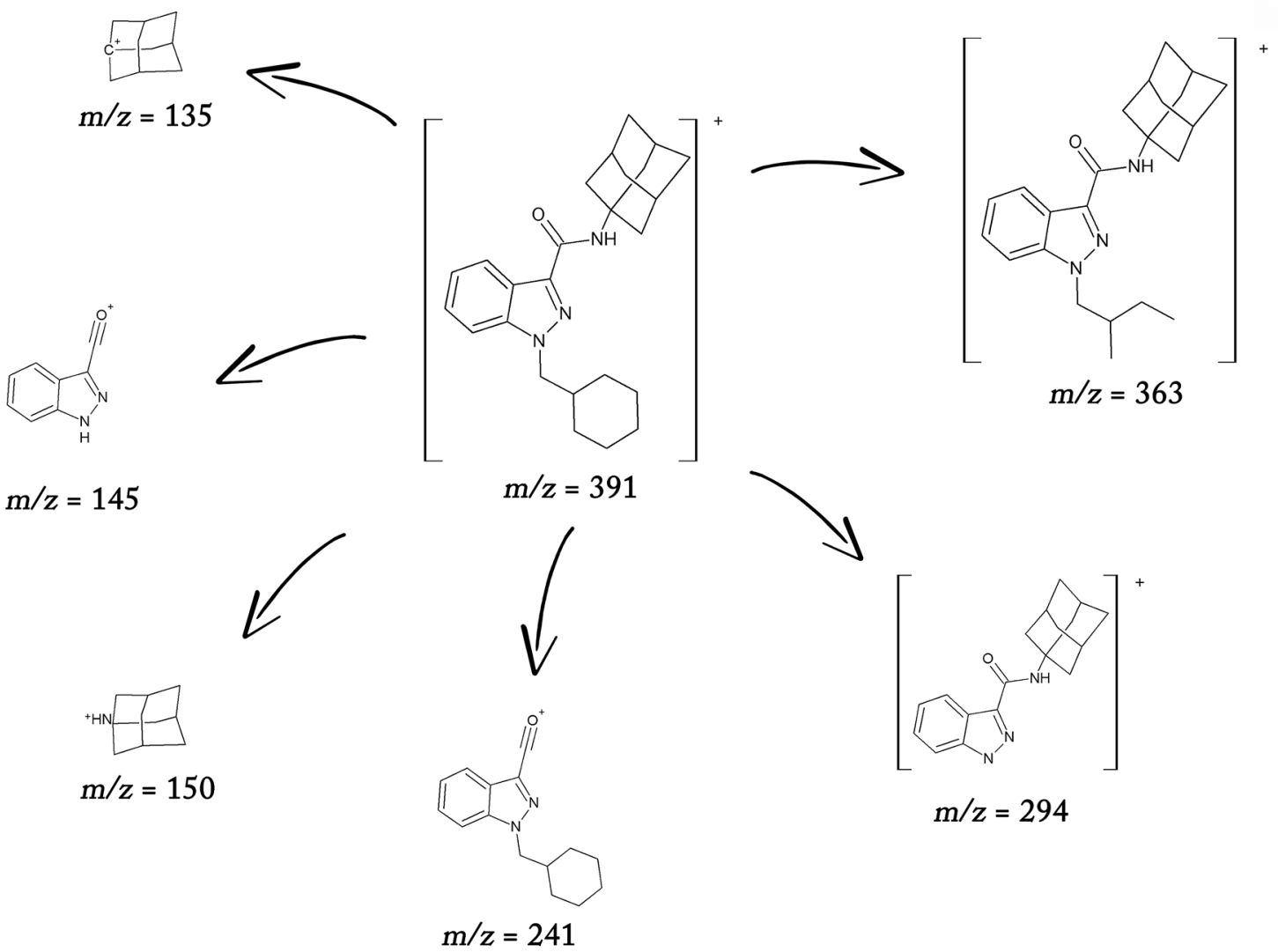

Fig. 3 a GC-electron ionization-MS spectrum of ACHMINACA and $\mathbf{b}$ its probable fragmentation pathways

The Raman spectrum (see Fig. S2) contained bands from group modes similar to those observed in the IR spectrum:

- carbonyl stretching and $\mathrm{N}-\mathrm{H}$ bending vibrations at 1660 and $1530 \mathrm{~cm}^{-1}$, respectively, similar positions as in the IR spectrum;

- strong bands from symmetric stretching modes of an aromatic ring appearing at positions $1617 \mathrm{~cm}^{-1}$ and
$1576 \mathrm{~cm}^{-1}$, and weak signal from asymmetric vibrations at $1494 \mathrm{~cm}^{-1}$.

According to the signal of the PDA detector, two maxima (at $210 \mathrm{~nm}$ and at $302 \mathrm{~nm}$ ) were observed on the UV-Vis spectrum of ACHMINACA (see Fig. S3). 
Table 1 High-resolution mass spectrometry (HR-MS) of $[\mathrm{M}+\mathrm{H}]^{+}$ ion and direct flow injection $\mathrm{MS}^{2}$ data of ACHMINACA

\section{HR-MS:}

\begin{tabular}{|c|c|c|c|}
\hline $\begin{array}{l}\text { Theoretical mass } \\
{[\mathrm{M}+\mathrm{H}]^{+}(\mathrm{Da})}\end{array}$ & $\begin{array}{l}\text { Experimental } \\
\text { mass }[\mathrm{M}+\mathrm{H}]^{+} \\
(\mathrm{Da})\end{array}$ & $\Delta \mathrm{mDa} \Delta \mathrm{ppm}$ & Formula \\
\hline 92.27019 & 392.27011 & -0.08 & $\mathrm{C}_{25} \mathrm{H}_{34} \mathrm{~N}_{3} \mathrm{O}$ \\
\hline
\end{tabular}

Direct flow injection $\mathbf{M S}^{2}$ :

\begin{tabular}{ll}
$m / z$ & Relative intensity $(\%)$ \\
132.9 & 7.2 \\
134.8 & 100 \\
136.0 & 2.3 \\
185.8 & 2.8 \\
247.1 & 1.3 \\
253.0 & 2.1 \\
257.5 & 21.5 \\
258.7 & 11.0 \\
314.1 & 4.1 \\
317.4 & 1.8 \\
329.6 & 2.1 \\
330.3 & 1.9 \\
349.5 & 1.7 \\
352.3 & 1.5 \\
366.2 & 1.6 \\
\hline
\end{tabular}

For structures of $\mathrm{MS}^{2}$ product ions, see Fig. 4

\section{NMR spectroscopy}

The ${ }^{1} \mathrm{H}$ and ${ }^{13} \mathrm{C}$ spectra of ACHMINACA in $\mathrm{CDCl}_{3}$ are shown in Figs. S4 and S5, respectively. The structural assignment of ${ }^{1} \mathrm{H}$ and ${ }^{13} \mathrm{C}$ signals was conducted on the basis of $2 \mathrm{D}$ correlation spectra and 1D s-TOCSY technique used for the overlapping high field signals (see Figs. S6-S12). For the TOCSY, selective excitations of 4.17 , and $2.23 \mathrm{ppm}{ }^{1} \mathrm{H}$ nuclei were employed, generating the 1D spectra showing only signals from cyclohexylmethyl and adamantyl proton spin systems, respectively (see Fig. S10 and S11). The structural assignment for nuclei of the cyclohexyl group was additionally facilitated using the refocused 1,1-ADEQUATE technique optimized for $\mathrm{CH}_{\mathrm{n}}$ groups, with $\mathrm{n}$ greater than 1 . Its signals gave direct information about two bond ${ }^{1} \mathrm{H}-{ }^{13} \mathrm{C}$ connectivities and indirect information about one bond ${ }^{13} \mathrm{C}-{ }^{13} \mathrm{C}$ connectivities (Fig. S12). Table 2 presents the description of ${ }^{1} \mathrm{H}$ and ${ }^{13} \mathrm{C}$ signals and the most important correlations from $2 \mathrm{D}$ spectra.

\section{X-ray diffraction}

The seized material was analyzed with powder X-ray diffraction (see Fig. S13). Following parameters were determined on the basis of powder data: the crystal system - monoclinic; space group - $\mathrm{P} 2{ }_{1} / \mathrm{c} ; \mathrm{a}[\AA]=16.849(11) ; \mathrm{b}[\AA]=12.502(6)$; $\mathrm{c}[\AA]=21.752(16) ; \beta\left[^{\circ}\right]=104.66(4) ; \mathrm{V}\left[\AA^{3}\right]=4433(5) ; \mathrm{Z}=8$.
Fig. 4 Fragmentation pathways of ACHMINACA by electrospray ionization-mass spectrometry
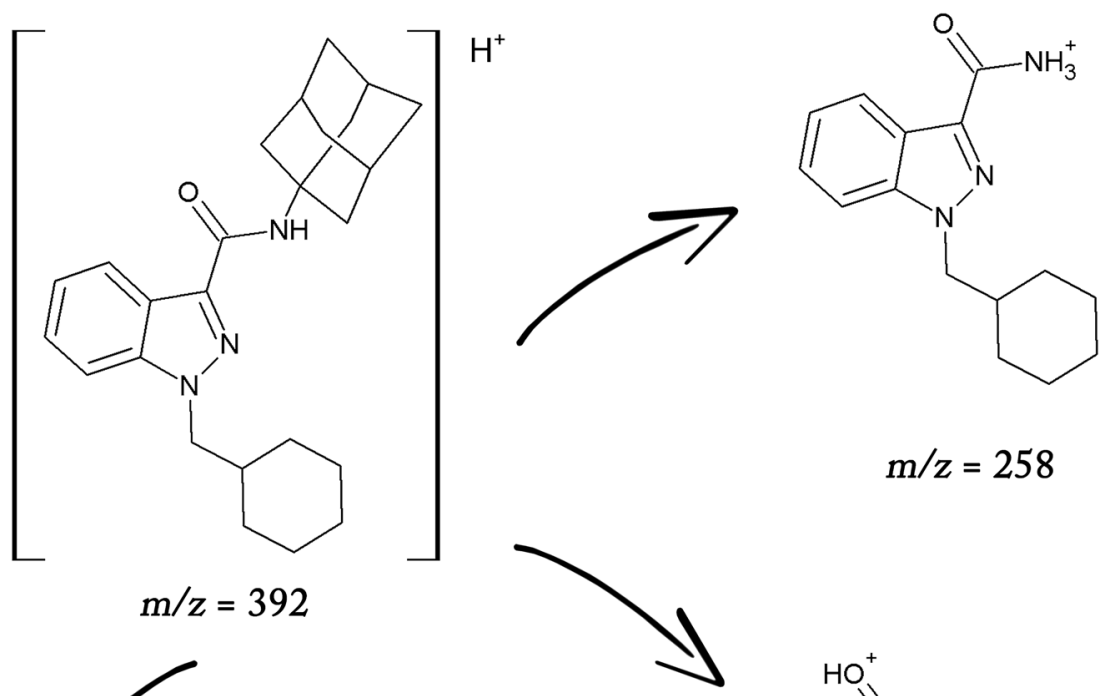

$\mathrm{m} / z=258$<smiles>OC(=[OH+])c1nn(CC2CCCCC2)c2ccccc12</smiles>

$\mathrm{m} / \mathrm{z}=259$ 
Table 2 Nuclear magnetic resonance spectroscopic data of ACHMINACA in $\mathrm{CDCl}_{3}$

\begin{tabular}{|c|c|c|c|c|c|}
\hline No. & ${ }^{1} \mathrm{H}$ & ${ }^{13} \mathrm{C}$ & COSY & $\begin{array}{l}\text { HMBC and } \\
\text { 1,1-ADEQUATE }\end{array}$ & NOESY \\
\hline 3 & - & 138.0 & - & - & - \\
\hline $3^{\prime}$ & - & 122.7 & - & - & - \\
\hline 4 & $8.38(\mathrm{dt}, J=8.3,1.0 \mathrm{~Hz}, 1 \mathrm{H})$ & 123.0 & $\begin{array}{l}\mathrm{H} 5 \\
\text { Overlapped H6 and H7 }\end{array}$ & $\mathrm{C} 6, \mathrm{C} 7{ }^{\prime}, \mathrm{C} 3, \mathrm{C} 7$ & H5 \\
\hline 5 & $7.23(\mathrm{ddd}, J=8.0,4.6,2.9 \mathrm{~Hz}, 1 \mathrm{H})$ & 122.2 & Overlapped $\mathrm{H} 6$ and $\mathrm{H} 7$ & $\mathrm{C} 7, \mathrm{C} 6, \mathrm{C} 7^{\prime}, \mathrm{C} 3^{\prime}$ & - \\
\hline 6 & $7.37(\mathrm{~m}, 1 \mathrm{H})$ & 126.4 & - & $\mathrm{C} 4$ or $\mathrm{C}^{\prime}$ & - \\
\hline 7 & $7.37(\mathrm{~m}, 1 \mathrm{H})$ & 109.3 & & $\mathrm{C} 4$ or $\mathrm{C}^{\prime}$ & $\mathrm{H} 1 \mathrm{a}$ \\
\hline $7^{\prime}$ & - & 141.4 & - & - & - \\
\hline $1 \mathrm{a}$ & $4.17(\mathrm{~d}, J=7.3 \mathrm{~Hz}, 2 \mathrm{H})$ & 55.6 & $\mathrm{H} 2 \mathrm{a}$ & $\mathrm{C} 7{ }^{\prime}, \mathrm{C} 2 \mathrm{a}, \mathrm{C} 3 \mathrm{a}$ & $\mathrm{H} 3 \mathrm{a}^{\mathrm{ax}}, \mathrm{H} 3 \mathrm{a}^{\mathrm{eq}}$ \\
\hline $2 \mathrm{a}$ & $1.98(\mathrm{~m}, 1 \mathrm{H})$ & 38.7 & $\mathrm{H} 3 \mathrm{a}^{\mathrm{ax}}, \mathrm{H} 3 \mathrm{a}^{\mathrm{eq}}$ & $C 3 a, C 1 a$ & $\mathrm{H} 3 \mathrm{a}^{\mathrm{eq}}, \mathrm{H} 4 \mathrm{a}^{\mathrm{ax}}$ \\
\hline $3 \mathrm{a}$ & $\begin{array}{l}1.59 \mathrm{eq}(\mathrm{dd}, J=13.0,2.4 \mathrm{~Hz}, 2 \mathrm{H}) \\
1.01 \mathrm{ax}(\mathrm{qd}, J=12.0,3.1 \mathrm{~Hz}, 2 \mathrm{H})\end{array}$ & 30.9 & $\begin{array}{l}\mathrm{H} 4 \mathrm{a}^{\mathrm{ax}}, \mathrm{H} 4 \mathrm{a}^{\mathrm{eq}} \\
\mathrm{H} 3 \mathrm{a}^{\mathrm{eq}}, \mathrm{H} 4 \mathrm{a}^{\mathrm{eq}} \mathrm{H} 4 \mathrm{a}^{\mathrm{ax}}\end{array}$ & $\begin{array}{l}C 2 a, C 4 a \\
C 2 a, C 4 a\end{array}$ & $\begin{array}{l}\mathrm{H} 4 \mathrm{a}^{\mathrm{eq}}, \mathrm{H} 4 \mathrm{a}^{\mathrm{ax}} \\
\mathrm{H} 4 \mathrm{a}^{\mathrm{eq}}\end{array}$ \\
\hline $4 \mathrm{a}$ & $\begin{array}{l}1.71 \mathrm{eq}(\mathrm{m}, 2 \mathrm{H}) \\
1.19 \mathrm{ax}(\mathrm{m}, 2 \mathrm{H})\end{array}$ & 25.7 & $\begin{array}{l}\mathrm{H} 4 \mathrm{a}^{\mathrm{ax}} \\
-\end{array}$ & - & - \\
\hline $5 \mathrm{a}$ & $\begin{array}{l}1.66 \mathrm{eq}(\mathrm{m}, 1 \mathrm{H}) \\
1.18 \mathrm{ax}(\mathrm{m}, 1 \mathrm{H})\end{array}$ & 26.2 & - & $\begin{array}{l}- \\
C 4 a\end{array}$ & - \\
\hline $1 b$ & - & 162.1 & - & - & - \\
\hline $2 b$ & $6.81(\mathrm{~s}, 1 \mathrm{H})$ & - & $\mathrm{H} 4 \mathrm{~b}$ & $\mathrm{C} 1 \mathrm{~b}, \mathrm{C} 3 \mathrm{~b}, \mathrm{C} 4 \mathrm{~b}$ & $\mathrm{H} 4 \mathrm{~b}$ \\
\hline $3 b$ & - & 51.8 & - & - & - \\
\hline $4 b$ & $2.21(\mathrm{~d}, J=2.6 \mathrm{~Hz}, 6 \mathrm{H})$ & 41.9 & H5b, H6b' & $\mathrm{C} 3 \mathrm{~b}, \mathrm{C} 5 \mathrm{~b}, \mathrm{C} 6 \mathrm{~b}$ & $\mathrm{H} 5 \mathrm{~b}, \mathrm{H} 6 \mathrm{~b}$ \\
\hline $5 b$ & 2.14 (brs, 3H) & 29.6 & H6b, H6b' & $\mathrm{C} 3 \mathrm{~b}, \mathrm{C} 6 \mathrm{~b}$ & H6b, H6b' \\
\hline $6 b$ & $1.77(\mathrm{brd}, J=11.7 \mathrm{~Hz}, 3 \mathrm{H})$ & 36.5 & - & $\mathrm{C} 5 \mathrm{~b}$ & - \\
\hline $6 b$ & $1.72(\mathrm{brd}, J=12.1 \mathrm{~Hz}, 3 \mathrm{H})$ & & - & $\mathrm{C} 5 \mathrm{~b}, \mathrm{C} 4 \mathrm{~b}$ & - \\
\hline
\end{tabular}

$\operatorname{COSY}{ }^{1} \mathrm{H}-{ }^{1} \mathrm{H}$ correlation spectroscopy, $H M B C{ }^{1} \mathrm{H}^{-13} \mathrm{C}$ heteronuclear multiple bond correlation spectroscopy, 1,1-ADEQUATE refocused 1,1 adequate sensitivity double quantum transfer spectroscopy, NOESY ${ }^{1} \mathrm{H}-{ }^{1} \mathrm{H}$ nuclear Ovenhausen effect spectroscopy. For carbon skeleton numbers of ACHMINACA, see Fig. 1

${ }^{a} \mathrm{C}-\mathrm{H}$ correlations from 1,1-ADEQUATE are listed with italic font
For the crystal structure solution, a single crystal measurement was conducted. Two independent ACHMINACA conformers (see Fig. 5) were observed in the crystal net (see Fig. S14). The single-crystal data and parameters from structure refinement are presented in Table 3.

\section{Discussion}

Spectroscopic techniques are fundamental for the identification of new psychoactive substances. In the case of ACHMINACA, only the most basic spectra like FTIR, EI-MS, and ${ }^{1} \mathrm{H}$ NMR were reported by a few institutions $[18,19]$. Analogous data were collected in our laboratory and stay in good agreement with the reports cited above. Additional techniques of ESI-MS (Fig. 4), Raman (Fig. S2) and UV-VIS (Fig. S3) spectroscopies were employed in the present study for further structural characterization of ACHMINACA allowing to extend the identification possibility of the most important structural ACHMINACA features, e.g., the presence of the heteroaromatic core and of the secondary amide group.

Although the discrimination of 1-adamantyl and 2-adamantyl isomers of other synthetic cannabinoids using GC-MS was reported [22], no similar data are available for ACHMINACA. For this reason, 2D NMR techniques (Table 2, Figs. S6-S12) were applied for the precise determination of ACHMINACA regioisomerism. ${ }^{1} \mathrm{H}$ and ${ }^{13} \mathrm{C}$ signals assigned for aromatic nuclei and their correlations resembled the resonance patterns of typical $1 H$-indazole carboxamides. Moreover, NOESY correlation between H7 and H1a clearly implied that the methyl cyclohexyl substituent is attached at position 1 of the aromatic moiety. The NOESY and COSY correlations of amide and adamantyl protons indicated the quaternary character of the adamantyl carbon atom connected to the amide nitrogen.

Although the techniques of molecular spectroscopy are the first choice for the structural characterization of novel designer drugs, $\mathrm{X}$-ray diffraction methods may also be employed because most of the materials containing 


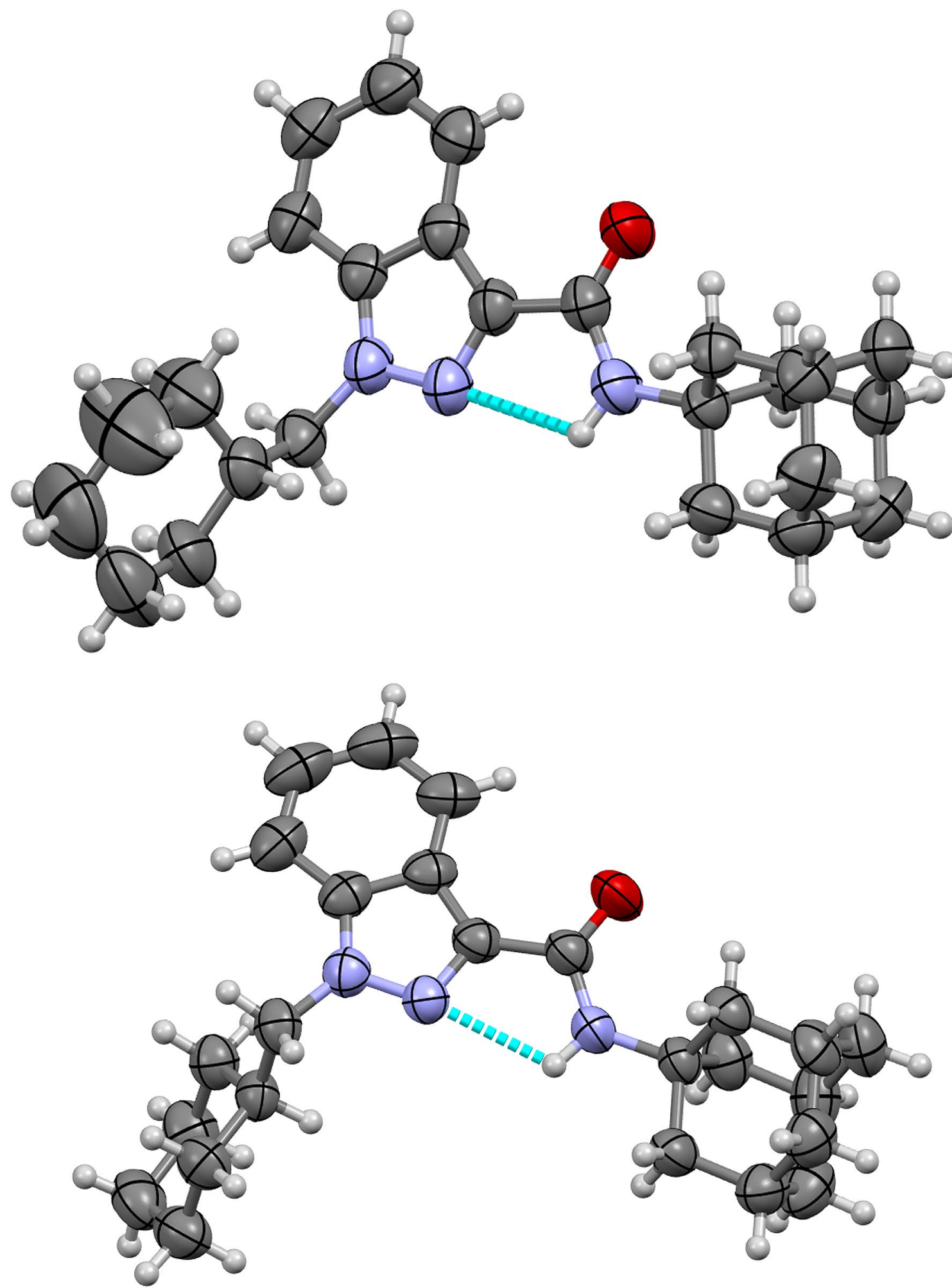

Fig. 5 Structures of ACHMINACA conformers observed in the crystal of the seized sample 
Table 3 Single-crystal X-ray diffraction and structure refinement data of ACHMINACA

\begin{tabular}{|c|c|}
\hline Empirical formula & $\mathrm{C}_{25} \mathrm{H}_{33} \mathrm{~N}_{3} \mathrm{O}$ \\
\hline Formula weight & 391.54 \\
\hline Temperature & 293(2) K \\
\hline Wavelength & $1.54184 \AA(\mathrm{Cu}$ rotating anode $)$ \\
\hline Crystal system & Monoclinic \\
\hline Space group & $\mathrm{P} 2{ }_{1} / \mathrm{c}$ \\
\hline \multirow[t]{3}{*}{ Unit cell dimensions } & $a=16.867(1) \AA$ \\
\hline & $\mathrm{b}=12.515(1) \AA$ \\
\hline & $\begin{array}{l}c=21.745(1) \AA \\
\beta=104.65(1)^{\circ}\end{array}$ \\
\hline Volume & $4440.9(5) \AA^{3}$ \\
\hline $\mathrm{Z} / \mathrm{Z}$ & $8 / 2$ \\
\hline Density (calculated) & $1.171 \mathrm{~g} \mathrm{~cm}^{-3}$ \\
\hline Absorption coefficient & $0.557 \mathrm{~mm}^{-1}$ \\
\hline $\mathrm{F}(000)$ & 1696 \\
\hline Crystal size & $0.34 \times 0.3 \times 0.28 \mathrm{~mm}^{3}$ \\
\hline Independent reflections & $8062[\mathrm{R}(\mathrm{int})=0.0631]$ \\
\hline Absorption correction & None \\
\hline Refinement method & Full-matrix least-squares on $\mathrm{F}^{2}$ \\
\hline Data/parameters & $8062 / 523$ \\
\hline $\mathrm{H}$-atom positions & Calculated/riding \\
\hline Goodness-of-fit on $\mathrm{F}^{2}$ & 1.054 \\
\hline Final $R$ indices $[I>2 \operatorname{sigma}(I)]$ & $\mathrm{R} 1=0.0711, \mathrm{wR} 2=0.1925$ \\
\hline $\mathrm{R}$ indices (all data) & $\mathrm{R} 1=0.0802, \mathrm{wR} 2=0.2054$ \\
\hline Largest diff. peak and hole & 0.37 and -0.23 e. $\AA^{-3}$ \\
\hline
\end{tabular}

new illegal substances have a solid form with a developed crystalline structure. The seized sample of ACHMINACA was analyzed by powder and single-crystal X-ray diffractometers without any sample pretreatment. The former technique allowed to determine the space group and lattice parameters of the examined material, but the crystal structure was not possible. A single crystal was successfully separated from the crude sample and examined by single-crystal diffraction giving the values of unit cell parameters similar to those in powder diffraction (Table 3). The obtained structure consisted of two ACHMINACA conformers differing only in the orientation of cyclohexyl moiety (Fig. 5). Both X-ray diffraction methods can be successfully utilized for the noninvasive characterization of materials containing synthetic cannabinoids. The single crystal experiment may even be used as a stand-alone technique for the purpose of complete identification replacing the long analytical process employing a wide array of molecular spectroscopy techniques.

\section{Conclusions}

ACHMINACA, the N-(adamantan-1-yl)1-(cyclohexylmethyl)-1H-indazole-3-carboxamide, is one of the novel synthetic cannabinoids, an analog of APINACA with the cyclohexylmethyl group in place of the pentyl chain. This study presented the complete structural characterization of this psychoactive compound obtained by GC-MS, ATR-FTIR spectroscopy, Raman spectroscopy, 1D and 2D NMR, LC--PDA-MS, and powder and single-crystal $\mathrm{X}$-ray diffraction. The results not only confirm the scantily provided data concerning ACHMINACA, but also significantly broaden the knowledge about the compound structure and extending the possibility of its orthogonal analysis.

Acknowledgments We gratefully acknowledge the use of the facilities of the Ecotech-Complex in Lublin, under project number UDA-POIG.02.01.00-06-212/09-03.

\section{Compliance with ethical standards}

Conflict of interest There are no financial or other relations that could lead to a conflict of interest.

Ethical approval This article does not contain any studies with human participants or animals performed by any of the authors.

Open Access This article is licensed under a Creative Commons Attribution 4.0 International License, which permits use, sharing, adaptation, distribution and reproduction in any medium or format, as long as you give appropriate credit to the original author(s) and the source, provide a link to the Creative Commons licence, and indicate if changes were made. The images or other third party material in this article are included in the article's Creative Commons licence, unless indicated otherwise in a credit line to the material. If material is not included in the article's Creative Commons licence and your intended use is not permitted by statutory regulation or exceeds the permitted use, you will need to obtain permission directly from the copyright holder. To view a copy of this licence, visit http://creativecommons.org/licenses/by/4.0/.

\section{References}

1. EMCDDA (2019) EU drug markets report 2019. EMCDDA. Europol Luxemburg. https://doi.org/10.2810/561192 (open access article)

2. UNODC (2020) World drug report 2020 booklet 4 - Cross-cutting issues: evolving trends and new challenges. https://wdr.unodc .org/wdr2020/field/WDR20_BOOKLET_4.pdf (open access article)

3. Lindigkeit R, Boehme A, Eiserloh I, Luebbecke M, Wiggermann M, Ernst L, Beuerle T (2009) Spice: a never ending story? Forensic Sci Int 191:58-63. https://doi.org/10.1016/j.forsc iint.2009.06.008

4. Wiley JL, Marusich JA, Huffman JW (2013) Moving around the molecule: relationship between chemical structure and in vivo activity of synthetic cannabinoids. Life Sci 97:55-63. https://doi. org/10.1016/j.lfs.2013.09.011 
5. Choi H, Heo S, Kim E, Hwang BY, Lee C, Lee J (2013) Identification of (1-pentylindol-3-yl)-(2,2,3,3-tetramethylcyclopropyl) methanone and its 5-pentyl fluorinated analog in herbal incense seized for drug trafficking. Forensic Toxicol 31:86-92. https://doi. org/10.1007/s11419-012-0170-5

6. Shevyrin V, Melkozerov V, Nevero A, Eltsov O, Baranovsky A, Shafran Y (2014) Synthetic cannabinoids as designer drugs: new representatives of indol-3-carboxylates series and indazole3 -carboxylates as novel group of cannabinoids. Identification and analytical data. Forensic Sci Int 244:263-275. https://doi. org/10.1016/j.forsciint.2014.09.013

7. Uchiyama N, Asakawa K, Kikura-Hanajiri R, Tsutsumi T, Hakamatsuka T (2015) A new pyrazole-carboxamide type synthetic cannabinoid AB-CHFUPYCA [ $N$-(1-amino-3-methyl-1-oxobutan2-yl)-1-(cyclohexylmethyl)-3-(4-fluorophenyl)- $1 H$-pyrazole5 -carboxamide] identified in illegal products. Forensic Toxicol 33:367-373. https://doi.org/10.1007/s11419-015-0283-8

8. Langer N, Lindigkeit R, Schiebel H-M, Papke U, Ernst L, Beuerle $\mathrm{T}$ (2016) Identification and quantification of synthetic cannabinoids in "spice-like" herbal mixtures: update of the German situation for the spring of 2016. Forensic Sci Int 269:31-41. https ://doi.org/10.1016/j.forsciint.2016.10.023

9. Giorgetti A, Mogler L, Halter S, Haschimi B, Alt A, Rentsch D, Schmidt B, Thoma V, Vogt S, Auwärter V (2020) Four cases of death involving the novel synthetic cannabinoid 5F-Cumyl-PEGACLONE. Forensic Toxicol 38:314-326. https://doi.org/10.1007/ s11419-019-00514-w (open access article)

10. Worst TJ, Sprague JE (2015) The "pharmacophore rule" and the "spices". Forensic Toxicol 33:170-173. https://doi.org/10.1007/ s11419-014-0243-8

11. Bovens M, Bissig C, Staeheli SN, Poetzsch M, Pfeiffer B, Kraemer $T$ (2017) Structural characterization of the new synthetic cannabinoids CUMYL-PINACA, 5F-CUMYL-PINACA, CUMYL-4CNBINACA, 5F-CUMYL-P7AICA and CUMYL-4CN-B7AICA. Forensic Sci Int 281:98-105. https://doi.org/10.1016/j.forsc iint.2017.10.020

12. Jia W, Meng X, Qian Z, Hua Z, Li T, Liu C (2016) Identification of three cannabimimetic indazole and pyrazole derivatives, APINACA $2 H$-indazole analogue, AMPPPCA, and 5F-AMPPPCA. Drug Test Anal 9:248-255. https://doi.org/10.1002/dta.1967

13. Jankovics P, Váradi A, Tölgyesi L, Lohner S, Németh-Palotás J, Balla J (2012) Detection and identification of the new potential synthetic cannabinoids 1-pentyl-3-(2-iodobenzoyl)indole and 1-pentyl-3-(1-adamantoyl)indole in seized bulk powders in Hungary. Forensic Sci Int 214:27-32. https://doi.org/10.1016/j.forsc iint.2011.07.011

14. Uchiyama N, Kawamura M, Kikura-Hanajiri R, Goda Y (2012) Identification of two new-type synthetic cannabinoids,
$N$-(1-adamantyl)-1-pentyl-1H-indole-3-carboxamide (APICA) and $N$-(1-adamantyl)-1-pentyl- $1 H$-indazole-3-carboxamide (APINACA), and detection of five synthetic cannabinoids, AM-1220, AM-2233, AM-1241, CB-13 (CRA-13), and AM-1248, as designer drugs in illegal products. Forensic Toxicol 30:114-125. https://doi.org/10.1007/s11419-012-0136-7

15. Lee JH, Park HN, Leem T-S, Jeon J-H, Cho S, Lee J, Baek SY (2017) Identification of new synthetic cannabinoid analogue APINAC (adamantan-1-yl 1-pentyl-1H-indazole-3-carboxylate) with other synthetic cannabinoid MDMB (N)-Bz-F in illegal products. Forensic Toxicol 35:45-55. https://doi.org/10.1007/s1141 9-016-0331-z

16. Langer N, Lindigkeit R, Schiebel H-M, Ernst L, Beuerle T (2014) Identification and quantification of synthetic cannabinoids in 'spice-like' herbal mixtures: a snapshot of the German situation in the autumn of 2012. Drug Test Anal 6:59-71. https://doi. org/10.1002/dta.1499 (open access article)

17. Uchiyama N, Matsuda S, Kawamura M, Kikura-Hanajiri R, Goda Y (2013) Two new-type cannabimimetic quinolinyl carboxylates, QUPIC and QUCHIC, two new cannabimimetic carboxamide derivatives, ADB-FUBINACA and ADBICA, and five synthetic cannabinoids detected with a thiophene derivative $\alpha$-PVT and an opioid receptor agonist AH-7921 identified in illegal products. Forensic Toxicol 31:223-240. https://doi.org/10.1007/s1141 9-013-0182-9

18. SWGDRUG (2018) ACHMINACA. http://www.swgdrug.org/ Monographs/ACHMINACA.pdf. Accessed 20 Apr 2020

19. National Forensic Laboratory, Slovenia (2018) Analytical report: ACHMINACA. https://www.policija.si/apps/nfl_response_web/0_ Analytical_Reports_final/ACHMINACA-ID-1993-18_report.pdf. Accessed 20 Apr 2020

20. Gonzalez FR, Nardillo AM (1999) Retention index in temperature-programmed gas chromatography. J Chromatogr A 842:29_ 49. https://doi.org/10.1016/S0021-9673(99)00158-2

21. Sheldrick GM (2008) A short history of SHELX. Acta Cryst A64:112-122. https://doi.org/10.1107/S0108767307043930 (open access article)

22. Asada A, Doi T, Tagami T, Takeda A, Sawabe Y (2017) Isomeric discrimination of synthetic cannabinoids by GC-EI-MS: 1-adamantyl and 2-adamantyl isomers of $\mathrm{N}$-adamantyl carboxamides. Drug Test Anal 9:378-388. https://doi.org/10.1002/dta.2124 (open access article)

Publisher's Note Springer Nature remains neutral with regard to jurisdictional claims in published maps and institutional affiliations. 